\title{
A comparison of academic information portals
}

\author{
Tamara Pianos* \\ German National Library of Economics, Kiel, Germany
}

\section{Introduction: Information portals in Germany}

In Germany, there are a great number of portals. The academic information portal vascoda covers about 40 individual subject portals in many different fields. A study was conducted in 2007 to find out if and how these portals serve the needs of their target groups. In a first step, researchers were asked about their specific needs and wishes. ${ }^{1}$ In addition, the contents and search functions of several portals were evaluated. The major findings of this study and previous studies will be presented in this paper.

Vascoda is an interdisciplinary academic information portal. It started its services in 2003, and it was first based on meta-search-technology. Since the relaunch in November 2007, new search engine technology (FAST) searches in over 100 million datasets from over 100 databases of different providers. The search engine focuses exclusively on academic and scholarly contents. The German Research Foundation (DFG) initialized the creation of Virtual Libraries (ViFa) in 1998. Since then more than 30 Virtual Libraries were created at the special collections libraries and other institutions. The Virtual Libraries and other subject portals funded by the Federal Ministry of Education and Research can be accessed through vascoda.

In 2008 there are about 40 subject portals for many different subjects from Anglo-American Culture to Veterinary Medicine. The subject portals offer access to all kinds of information from specific databases to library catalogues and from internet resources to electronic journals. Most of the virtual libraries still offer a meta-search of different databases, they include different document supply services and a couple of other services.

Typical Contents of Subject Portals would be databases, publications and different services. Depending on the subjects the databases will be factual databases, library catalogues, bibliographical databases, full-text databases, journal databases, reference databases and subject directories. Different sorts of publications such as digitized content, full-text repositories, digital encyclopaedias, handbooks, journals and so on can be found. Mailinglists, event calendars and weblogs are also included in many subject portals. Many portals offer different services like: helpdesks, online reference, lists of new publications, newsletter, RSS-Feeds and more.

\footnotetext{
*Address for correspondence: Dr. Tamara Pianos, Organizational and Human Resources Development vascoda-Projects, ZBW - German National Library of Economics, Leibniz Information Centre for Economics, Düsternbrooker Weg 120, 24105 Kiel, Germany. Tel.: +49 431 8814-365; Fax: +49 431 8814-520; E-mail: t.pianos@ zbw.eu; URL: http://www.zbw.eu.

${ }^{1}$ A small number of librarians and other information specialists was also asked about their preferences in information portals. The focus of this paper will be on the findings from the interviews of academics.
} 
Apart from the subject portals organized in vascoda, there are also a couple of other subject portals in Germany created by learned societies or other special groups. Many other countries also offer a number of gateways. In many cases there are international co-operations on a subject level. ${ }^{2}$ In 2007 , a study was conducted by Heinold, Spiller \& Partners ${ }^{3}$ to find out if and how the subject portals meet the needs of their target groups.

\section{What do academics want?}

The answers to this question sound very simple sometimes even banal, yet the realization is often quite difficult. A number of studies have already tried to find out different aspects of what scientists and academics want. ${ }^{4}$

First and foremost: Keep it simple and straightforward. Academics want a straight forward and selfexplanatory navigation, preferably one search field plus an optional expert search. If there are too many options on the homepage, the users might be confused and leave right away. Academics want a comprehensive search covering all relevant information, a complete set of metadata plus abstract. They want complex and comprehensive search options, for example they want to be able to choose individual databases. They want one result set - not several sets sorted by database. This particular wish was mentioned very often, yet it is quite difficult to fulfil as long as many portals still work with meta-searches instead of search-engine technology. The same is true for sorting and drill down options for result sets or for full-text-search-options. The problem with these requirements is not only the availability of the right technological solution but also a question of rights and licences.

Many academics want the information "now or never and for free - or at least easy and not too expensive". Open access seems the best choice, but if the desired article etc. cannot be accessed directly

\footnotetext{
${ }^{2}$ The other portals are not part of this presentation. An overview over different portals in different countries by Eleanor Frierson can be found here: http://www.science.gov/communications/library/icstiJune72006NationalSciencePortals.ppt.

${ }^{3}$ Website of the firm: http://www.hspartner.de/jsp292/contentPath=hauptmenue/englisch.

${ }^{4}$ Studie der Firma Heinold, Spiller \& Partner zum Them "Virtuelle Fachbibliotheken im System der überregionalen Literatur- und Informationsversorgung: Studie zu Angebot und Nutzung der Virtuellen Fachbibliotheken", November 2007, not published. Other Papers and Studies in German: Weiterentwicklung der überregionalen Literaturversorgung Memorandum 1998, http://www.dfg.de/aktuelles_presse/reden_stellungnahmen/download/memo.pdf. Nutzung elektronischer Fachinformation, -publikation und -kommunikation in der Hochschulausbildung, Barrieren und Potenziale in der innovativen Mediennutzung im Lernalltag der Hochschulen Stefi Sozialforschungsstelle Dortmund, BMBF 2001, Kurzbericht und Endbericht unter: http://www.stefi.de/. Zukunft der wissenschaftlichen und technischen Information (Strategiekonzept), Arthur D. Little (A.D.L.), BMBF 2002, http://www.bmbf.de/pub/zukunft_der_wti_in_deutschland.pdf. Nutzungsanalyse des Systems der überregionalen Literatur- und Informationsversorgung: Teil I: Informationsverhalten und Informationsbedarf der Wissenschaft, Teil II: Zur Nutzung der SSG-Bibliotheken, Poll, Universitäts- und Landesbibliothek Münster, infas 2003, http:// www.dfg.de/forschungsfoerderung/wissenschaftliche_infrastruktur/lis/download/ssg_bericht_teil_1.pdf; http://www.dfg.de/ forschungsfoerderung/wissenschaftliche_infrastruktur/lis/download/ssg_bericht_teil_2.pdf. Das DFG-System der überregionalen Sammelschwerpunkte im Wandel; Anhang "Weiterentwicklung des SSG-Plans", DFG 2004, http://www.dfg.de/ forschungsfoerderung/wissenschaftliche_infrastruktur/lis/download/strategiepapier_ueberreg_lit_versorgung.pdf; http://www. dfg.de/forschungsfoerderung/wissenschaftliche_infrastruktur/lis/download/strategiepapier_ueberreg_lit_versorgung_tab.pdf. Strategische Erfolgsfaktoren von wissenschaftlichen Portalen: Content-StudieZB MED, Mummert 2004, http://www. dl-forum.de/dateien/Endbericht_Content-Studie_DL-Forum.pdf. Evaluation von vascoda.de aus BenutzersichtErgebnisse der Nutzerbefragung 2005Nutzer-befragung, IwFB ULB Münster 2005, http://www.dl-forum.de/dateien/Evaluation_vascoda_ Ergebnisse_Befragung_2005.pdf. Evaluation von vascoda.de aus BenutzersichtErgebnisse der Fokusgruppenbefragung 2005Fokus-gruppenIwFB+ULB, Münster 2006, http://www.dl-forum.de/dateien/vascoda_Ergebnisse_2005_Fokusgruppen. pdf. Richtlinien zur überregionalen Literaturversorgung der Sondersammelgebiete und der Virtuellen Fachbibliotheken, DFG 2006, http://www.dfg.de/forschungsfoerderung/wissenschaftliche_infrastruktur/lis/download/richtlinien_lit_versorgung ssg_0607.pdf. Wissenschaftliche Literaturversorgungs- und Informationssysteme: Schwerpunkte der Förderung bis 2015, DFG 2006, http://www.dfg.de/forschungsfoerderung/wissenschaftliche_infrastruktur/lis/download/positionspapier.pdf.
} 
and for free, access through document delivery must be fast, easy and reasonably priced. Most people are not willing to pay for metadata, but in many databases one has to pay for the display of the metadata. Hardly surprisingly, many academics hesitate when it comes to registrations. They want no registration at all - or only if one registration will suffice for many different services. Some quotes nicely illustrate the problem many people share today: "The problem is that I already have four pages full of passwords and logins in my diary. I think at least twice before I register for any other service ..." or "I would not want to register for individual portals but if I could register once and could use all services in Germany like I can use my library card for library loans in Germany - that would be useful".

\section{Why is it difficult to build the perfect portal?}

Comprehensiveness is desired but not easy to define and also difficult to realize. Probably every academic has a different view of what the perfect portal might look like depending on personal preferences and focus of research. A search including a vast amount of different databases cannot be tailor-made for an individual researcher. If complex search-options are needed there is a need for basic or better advanced search skills. Comprehensiveness is wanted by most people but when asked to define the aspects it is hard to grasp. Mostly important authors and journals are mentioned as indicators of comprehensiveness.

There are technical and licence restrictions that make it hard to realize the perfect portal. Licensed content cannot easily be covered. Licence situations vary from federal state to federal state, on-campus vs. off-campus etc. thus making it very difficult to understand why certain content can be found in one place but not in another - even if one uses the same portal. National licences and authentication tools will hopefully bring improvements in the near future.

\section{Examples of subject portals}

The subject portals covered by vascoda present themselves in many different ways. ${ }^{5}$ Many subject portals started out as portals that support navigation to different services. Up to now, a great number of subject portals still has many links on the homepage. MedPilot (www.medpilot.de) is the portal that has radically reduced the homepage to the basics. It has one search field and hardly anything else. In this case, this seems to be a very successful strategy.

\section{Success factors}

For a subject portal to be successful most of the following factors need to be fulfilled: one search covers most of the relevant content. The search-field needs a prominent position on the homepage. A common desire that is not often easily fulfilled is: metadata (and if at all possible abstracts) can be viewed free of charge. The content should be easily available - either through open access or through the integration of document supply.

It seems also very important to enhance information competence through tutorials, guided tours etc. Not every subject portal can be used as easily as Google, yet many searchers are very much used to the way Google works. If subject portals offer more complex services, there is a need for training and instruction.

\footnotetext{
${ }^{5}$ All the individual subject portals are listed under www.vascoda.de.
} 